\title{
Comment on Priming Skills of Autistic Twins and Yamaguchi (2006) Letter to the Editor: "Questionable Aspects of Oliver Sacks' (1985) Report', Journal of Autism and Developmental Disorders
}

\author{
Allan Snyder
}

Published online: 31 May 2007

(C) Springer Science+Business Media, LLC 2007

\section{Erratum to: J Autism Dev Disord} DOI: $10.1007 / \mathrm{s} 10803-006-0301-0$

In the References, there are two references to the 'Journal of International Neuropsyhological Society'. This is incorrect. The publication is the 'Journal of Integrative Neuroscience'.

In addition, there is a typographical error when referring to 'Sack, O. (1985)'. This should be 'Sacks, O. (1985)'. 